\title{
Reviewing Sustainable Sports Infrastructure: Implications for Sports Development in Nigerian Universities
}

\author{
AKANI, Chizy, BRISIBE, Warebi G* \\ Department of Architecture, Rivers State University, Port-Harcourt, Nigeria
}

*Corresponding Author: BRISIBE, Warebi G, Department of Architecture, Rivers State University, PortHarcourt, Nigeria

\begin{abstract}
The furtherance of Sports in tertiary institutions in the Nigerian Scenario currently faces major challenges. The primary purpose of university sports is gradually lost as fewer institutions get to participate or host as the years go by. The Rivers State University is one of these institutions facing such challenges despite its existence as one of the oldest universities in the region, with a large student population. The need to re-awaken student interests in sports has become prominent and infrastructure has been identified as responsible for the shortfall. This research project examines the situation in the Nigerian context. It considered the sustainability dimensions of sports infrastructure in a bid to provide a practicable solution to this daunting concern. Ultimately, the research culminated in the design of a modern sports complex for the Rivers State University which could be adopted in other institutions with similar challenges.
\end{abstract}

Keywords: sustainable sports infrastructure, sports participation

\section{INTRODUCTION}

The consideration that sports plays a major role in regulating physical and mental health as well as improving life expectancy is a global phenomenon, thusthe distinct recognition of sports value in the educational systems globally. In the Nigerian context, the inception of the Nigerian University Games (NUGA) in 1966 further establishes this recognition.

This bi-annual competition targeted atunifying Nigerian universities from across all geopolitical regions is hosted rotationally and largely dependent on established criteria related to the adequacy of sports facilities within the university institution. These dimensions advocate for the consideration of sports infrastructure in line with globally acceptable standards. Gbinijie (2001) records that infrastructure has remained a growingly worrisome challenge in the Nigerian sporting scenario, particularly in the tertiary education institutions, as little efforts are made at establishing adequate university sports facilities nationwide. This partly owes to the unsustainable practices which have polarized the Nigerian sports hemisphere over the years as regards infrastructure.

Sustainability as a global phenomenon is geared towards reducing the negative impact of human daily activities on the environment, and purposefully managing resources. This is inclusive of costs of waste recorded by the industry. These concerns within the practice have led to the establishment of agencies and programs like the Leadership in Environmental Awareness and Performance (LEAP), and the Environmental Protection Agency (EPA) to regulate the alignment for sustainability. Current practice thus dictates that it is imminent that public building structures are established in line with sustainability considerations. As regards sports, the British Association for Sustainable Sport (BASIS), the Dutch Sports Infrastructure (DSI) and the TU Delft Sports Engineering Institute, all present a cause for sports infrastructure to be sustainable in modern practice.

Nonetheless, Jeroh (2005) identifies that the deficiency of sports facilities remains the prime issue in sports management in Nigeria resulting in a dire lack of interest.Ekpe (2001) observes that the standard of sports cannot be devoid of the condition of facilities existent for the purpose.

With the absence of proper sports infrastructure, the Rivers State University presents a distinctive case as records of its participation and hosting of the prime Nigerian Universities Games remain unappealing. Against this daunting concern, this study investigates the scenario at the Rivers State University, Port Harcourt. It seeks to provide an architectural solution to the sports infrastructure, and 
Reviewing Sustainable Sports Infrastructure: Implications for Sports Development in Nigerian Universities

student well-being related issues with the design of a sustainable modern sports complex which will provide all the standard facilities, systems and equipment required for a University institution to host the Nigerian Universities Games (NUGA).

\subsection{Problem Statement}

Sports progression at the Rivers State University is currently daunted as the university has no recognizable sports facility. This has deprived the university the right of hos

Interest in sports at the Rivers State University is at its peak in recent times. Sports, particularly soccer, are played on any available space area. This is despite the low levels of awareness among students that there is a dedicated sports day in every week which is a primary part of the school curriculum. This has greatly affected the landscape turning green fields brown with dirt patches and creating ugly water troughs all over the place. Classrooms and learning studios have become alternative tennis courts when free, for want of recreation space. Car parks are alternative football fields, and high traffic/major roads, skating rinks. This has become a worrisome trend. In addition, a reduction in meaningful engagement level outside of the classroom is also identifiable based on frequent acts of restiveness. Furthermore, the Nigerian University Games introduced in 1966 has never been hosted at the Rivers State University. All these concerns result from the absence of necessary infrastructure and facilities which constitute the basic requirements for a sports complex. As such, it has become a necessity that adequate sports facility is provided within the university if the current status is expected to change and the recognized concerns attended to.

\subsection{Research Aim}

The main aim of this study is to provide a permanent solution to the infrastructure related concerns of sports and improve records through sustainable sports infrastructural design, at the Rivers State University.

\subsection{Research Justification}

The Rivers State University established in 1980, currently with an estimated student population of 22,000 and staff strength of 3,000 has no standard sports infrastructure. As such, it has never hosted the NUGA despite the yearning for sports. This is further evidenced by the regular indulgence in sports visible on the campus on a daily basis. These considerations present the need for sports infrastructure in the university as crucial.

\section{Literature REVIEW}

\subsection{Sports: The History and Origin of Infrastructure in Sports}

The scarcity of the relevant archaeological record concerning prehistoric sports makes it difficult to establish a definite origin as it is as old as the existence of man. However, it is likely that the first athletic events were contests of the physical skills most important in fighting, hunting, and warfare like races, throwing contests, target games, and combat sports (Loy \&Hesketh, 1995; Chick, Loy, \& Miracle, 1997; Guttmann, 2004). Multiple proponents have defined sport as an activity requiring direct physical competition with an opponent(s), under established procedures and rules, and defined criteria for determining victory (Poliakoff, 1987; Lombardo 2012).

The English Oxford Dictionary considers a sports complex as a centre offering a variety of different sports facilities, especially under one roof. The Great Soviet Encyclopedia (1979) enlists that a sports complex refers to individual buildings or groups of structures designed for exercising, sports training and practice, and competition in various sports. Stadiums are recognized as the first representation of infrastructure in sports. A sports stadium is recognized as a venue with the court or field of the given sport in the center surrounded by a large structure that serves as the seating for any fans or viewers. The history of sports stadia dates back to around 800 B.C. Here, stadia and hippodromes were beginning to be developed in Greece, hosting such sporting events as the Olympics. These were formed in all Greek cities where games were played (John \&Sheard, 2000). The word stadium was derived from the ancient Greek term "stade", which was a unit of measure that is said to be roughly 180 meters. Greece is also the home to the oldest known stadium, in Olympia, the home to the first ever Olympic Games in 776 BC. This Olympics consisted of just one event which was a sprint across the stadium. 
Reviewing Sustainable Sports Infrastructure: Implications for Sports Development in Nigerian Universities

Stadia at this time were built in a horseshoe shape and sometimes were cut out of a hillside so that excellent seating could be formed naturally. These hillside stadia led to the development of theatres of similar design, and later on amphitheatres, eventually leading to the development of the modern stadium. Amphitheatres are arenas that are surrounded on all sides by high rising seats that allowed for a maximum capacity of people to have a clear view. These Amphitheatres were used by Romans to stage combat, which was preferred by Romans over other events. These were initially built out of timber in B.C. but in A.D. they began using stone and concrete instead.

More recently, sports stadia have taken a much different look. Steel construction has completely changed the composite of stadia, and retractable roofs have allowed stadium owners to have either an indoor or outdoor environment depending on the weather. Indoor stadia are also known as domes and are seen prolifically in the northern United States. The term stadium is mostly used to describe those dedicated to outdoor sports such as football. Buildings for indoor sports such as basketball are usually known as arenas.

\subsection{Sports in University Institutions: Impact on Academic Performance and Well-Being}

Academic performance is considered to be the extent to which a student, teacher or institution has achieved their short or long term educational goals or expectations (Annie et al, 1996). The Cambridge University Reporter identifies that academic performance is defined by performance in examination and this is usually characterized by an overall annual performance which culminates in a Grade Point Average (GPA). Well-being on the other hand is considered as a state of being comfortable, healthy or happy (Merriam-Webster Dictionary).

Traditionally, participation in sports was said to make boys into men and help them appreciate teamwork, duty, sacrifice and dedication. Sports build character and engender the values of good sportsmanship in young men. As a result of this tradition, a number of researchers have argued that organized sports can play a beneficial role in the development of children into educated and wellrounded adults (Griffith, 2004). The World Health Organization (WHO, 2010) considers that adults require a minimum of 30 minutes of regular, moderate-intensity exercise for at least five days per week to remain active, and school-aged children should perform exercise 60 minutes each day for healthy behaviour. In terms of well-being, Mahoney et al. (2003) opines that sports participation enhances the capability of learning and acquiring new skills, setting goals, and recognizing factors which could aid in the achievement of desired outcomes. Hadavi et al (2014) concluded from a study that the need for acquisition of freshness, vitality and inner joy and peace of the soul was a motivating factor in both male and female participation in sports. Eccles et al (2003), and Covay andCarbonaro (2010) suggest that sports participation encourages skill development, self-confidence, self-control, effort building, and interaction with others as well as team work. Fejgin (1994) enlists that if the qualities of concentration/focus, self-discipline, perseverance, determination and hard work identifiable with sporting are transferred to academics, this could prove a strong signal for achieving good grades.

Prasad (2012) through a research using simple linear regression identified that the frequency of sports participation on a weekly basis had a positive impact on student grades.

In a study conducted by the Alberta Schools Athletic Association it was found that student-athletes are less likely to smoke and are less likely to report drinking more than once a week in comparison to non-athletic students (NHSAW, 2001). Theoretically, these studies perceive sports participation to be a protective factor against social ills. Dawkins (2006) examined the association between participation in school-based sports and substance abuse. Dawkins' study confirmed that, as sports fill up a students' time and motivate them toward healthy goals, use of tobacco and marijuana decline among student-athletes. Thus, sports are not only contributory to academic performance and well-being, but are a potentially important protective activity for young adults.

\subsection{Infrastructure and Sport Participation in Nigerian Tertiary Institutions}

Sailis\& Conway, et al., (2004) from a study of young people identified that even in their unstructured time, less than $2 \%$ of females and $6 \%$ of males were physically active during any given school day. These numbers were even lower where the school structure provided little or no infrastructure to allow for physical activity. Azizi et al. (2012) submits that bountiful evidence exists that only a small 
Reviewing Sustainable Sports Infrastructure: Implications for Sports Development in Nigerian Universities

percentage of the academic community welcomes university sports programs. A primary reason for the promotion of sports participation is the recognition that sports participation creates good health and well-being amongst several other positive effects for the society (Gratton 2004). Sports participation is greatly influenced by the quantity and quality of sport infrastructure available in an area (Atkinson, et al 2005; Haug et al., 2008). Hallmann et al (2011) notes that there are two prominently different factors which determine affect sports participation: firstly are the factors on the Individual Level they categorize as Sport Demand and second are factors on the Infrastructural Level considered as Sport Supply. A decent supply of nearly all kinds of sport infrastructure will have a positive effect on sports participation, as the more diverse the available sports infrastructure is, the greater the population it appeals to (Chad, et al., 2005; Haug, et al., 2008; Limstrand\&Reher, 2008). Lahsaizade (2007) investigated sports participation in Shiraz University and discovered infrastructure to have a significant effect. Mirzazadeh et al (2015) researched participation students in sports at several universities in Mashhad, Iran and discovered that besides self-motivation, availability of infrastructure and ease of access to it was the next most important factor. Londhe (2013) considered 33 colleges in Nashik district, India and discovered that the non-availability or inadequacy of sports facilities had an adversely negative effective on sports participation and performance. Robert (2012) investigated the impact of Campus Recreational Sports Facilities and Programs on Recruitment and Retention among African American Students. His investigation revealed that $60 \%$ of the male students considered the availability of recreational sports a major deciding factor in attending a college and $68 \%$ of the men reported that the availability of recreational sports was important/very important in deciding to continue attending the college.

Adesoye (1989) reported that some of the tertiary institutions in Nigeria could not stand the test against their counterparts due to their poor sports management practices. For Omolawon (2000), the role of sports management cannot be over-emphasized, because sporting facilities are regarded as necessary to facilitate the numerous activities involved in sports. Amusa (1986) conducted a pilot study on the influence of variables such as incentives, adequate facilities, equipment, and human relations in participation and performance in sports. He equally revealed that standard facilities are an essential pre-requisite to participation and excellent performance in sports activities at all levels..Fasan(2000) suggests that availability and accessibility of these sport facilities to the students will surely promote instructions, training and acquisition of skills.

Amuche (1986) advocated that for effective sports management in tertiary institutions in Nigeria, facilities just like other elements are the factors that determine the viability of any sports program. Atoyebi (1992) stated that adequate planning and construction of facilities are necessary if performance and participation in inter collegiate sports programme will be appreciated and enjoy good management. A few examples of such improved sports facilities include among others, synthetic and cinder tracks. The place of proper maintenance culture in sports management cannot be over looked. This is because it is the only way by which the life span of the facilities can be extended. Corroborating this idea, Adesanya (1992) maintained that well organized program for care of facilities; equipment and supplies will pay off in increased longevity. He therefore advocated for maintenance staff that will be responsible for the care of the facilities. Seidar (1987) believed that it is on a well maintained facility that value for the participant and the equipment used for the sporting activities could be utilized.

In realization of the place of good maintenance culture in sports management, Obiyemi (1987) set out plans for facilities maintenance. Accordingly, he was of the opinion that proper maintenance plans for sports facilities are not achieved by chance or accident, but rather they are achieved by initiative and actions of knowledgeable people acting individually or in groups and agencies. He therefore assessed that in an effort to provide satisfactory maintenance of sports facilities, plans for these should form a corporate heading in the budget of a seasoned sports manager. Seidar (1997) reported that when facilities have maintenance problems they can be due to inadequate budgetary provision or inefficient custodial staff. In this regard, therefore, the manager should be responsible for ensuring that the maintenance of facilities acquired for sports activities is guaranteed since maintenance is an important means of checking the rate and intensity of depreciation of most sports facilities. Although adequate facilities are necessary for effective instruction in physical education and sports, it is the responsibility of the management to provide adequate space/facilities, equipment and personnel for the sporting program (Venkatewarlu, 2000). 
Reviewing Sustainable Sports Infrastructure: Implications for Sports Development in Nigerian Universities

The University of Ibadan hosted the first NUGA from 22nd to 29th of March, 1966 thereby signaling the start of the biennial events, which has been staged more than twenty times over the last 50 years. So far, only ten Universities have rotated the hosting of the games out of the one hundred and seventy universities existing in the country.

\subsection{Sustainability and the Development of Modern Sports Infrastructure}

At the World Conference on Sport and the Environment in 1995 hosted by The International Olympic Committee (IOC) and the United Nations Environment Programme (UNEP), sports was embraced as the third dimension in environment concernson the agenda for the 4th School Forum at GenovaArenzano 2003. Since then, the major crisis western countries have faced spending millions on major sports infrastructure has become a focus of concern as they are left to decay after competitions are over. Avoiding irrelevancies and considering the future of these installations has become the main objective of most stakeholders involved in this kind of projects. The current trending ideology is to transform them from an iconic venue designed for a specific event into a daily working, living and leisure attraction pole that will participate in the regeneration of an entire urban area. The integration of these infrastructures within the local eco-system based on proper planning, how they can boost business and activities, and how they can help restructure a whole urban fabric should become the main focus of thought. The idea is to build flexible and open infrastructure which will not only shine during a limited amount of time, but which will also have a real sustainable impact.

Bogar (2012) analyzed recent trends in the design and construction of recreational sports facilities in the colleges in the U.S and made several observations. Functions involving academics, health, wellness, and sport considered as important had been provided for in these college sports facilities. However, in the new trend, unique features such as climbing walls, rooftop playing fields, food service, counseling centers, convenience stores, and campus police stations had also been integrated into these facilities. Analyzing how construction trends of Universities sport facilities will be affected by financial crisis, Antón (2011) presents results that a high percentage of the respondents opined that the use, construction and renewal of sport facilities in Spanish Universities would increase continuously for the next three years. It was further observed that wellness and recreational centres are perceived to be more successful than other extracurricular options like arts, with regards to architectural trends.

Just like energy conservation and emissions reduction, de-constructability and flexibility has become a major consideration in the new sustainability considerations for sports infrastructure globally. John Barrow (Populous) designer of the London Olympic Stadium, explains that it will be able to host 80,000 people during the Olympics, but will be reduced to somewhere around 25,000 seats after the Games. The approach was even more radical with the $100 \%$ temporary basketball venue $(12,000$ seats).

These observations present cause for dire consideration in the recent global context of sustainability. The social, economic and environmental concerns associated with the construction of sports infrastructure need to be deeply considered such that every infrastructural intervention is meaningful. This would involve the purposeful tailoring and management of both financial and non-financial resources, as well as the unique direction of the intervention relative to the social times and predominant activities of interest in current university sports undertakings. The British Association for Sustainable Sport (BASIS), the Dutch Sports Infrastructure (DSI) and the TU Delft Sports Engineering Institute, all present a cause for sports infrastructure to be sustainable in modern practice.

\section{RESEARCH METHODOLOGY}

This research was carried out using mixed methods approach. The research drew largely on qualitative research techniques. Cross-sectional survey design was used for this study, and this method was chosen because the study centered on human factors. The target population included 22,000 students enrolled at the Rivers State University. The relevant data for the study was collected from both primary and secondary sources. Formal (one-to-one) interviews were undertaken with the SUG directors of sports and socials, the environmental sciences faculty director of socials, and the director of socials of the department of architecture. Informal interviews and focus group sessions with students were also undertaken. These interviews afforded for ample information relevant to the research. 

Universities

An extensive review of books, journals and other recorded research related to the study was undertaken. Government regulations, institutional guidelines and professional architectural standards as concerned with university sports and infrastructure were also drawn upon. Similar institutions boasting facilities related to this research in foreign countries were also reviewed and adopted as case studies for this work.

This involved personal visits made to related sites and similar institutions of interest to gather firsthand information on existing infrastructure. A survey of the proposed project site at the Rivers State University was also undertaken with the purpose of identifying the unique concerns as well as location dependent issues. Sourcing of layout plans, templates and other proposed site information was done.

Criteria for Selection of Case Studies included: Similarities to the study (shared functions and nature of spaces, facilities), Uniqueness or Relevance to the study (available lessons adaptable to the study) and Geographical differences.

On this basis, the four case studies were selected which included two in the local or internal geographical context and another two in the international or external geographical context. In the local context, the University of Port Harcourt Sports Complex, Choba and the University of Benin Sports Complex, Benin Citywere selected while the Northumbria University Sports Complex, Newcastle Upon Tyne and the California State University Wildcat Recreation Center, Chico were considered in the international context.

\section{DESIGN PRESENTATION AND ANALYSIS}

\subsection{Criteria for Appraisal of Case Studies}

The case studies were appraised based on outlined considerations in the 'Neufert Architects Data: 4th Edition', the 'Design Objectives of Whole Building Design' (Prowler, 2009) and 'Architectural Design: Theory and Design', (Rao, 2009). These considerations include the following;

- Location: Viability as to whether the project is properly situated

- Accessibility: This involves consideration for ease of reach or access for the users

- Building Character/Visual Access: Concerned with how easily the physical structure relates with its purpose of use, making it easy to identify.

- Site Zoning/Arrangement: This reviews the allotment of land area for various building structures or outdoor functions.

- Site Circulation and Movement: Considers the organization and planning of vehicular, cycling and movement routes within the site, as well as user/customers and service/delivery routes.

- Orientation/ Layout: involves the positioning of structures or facilities on site in response to certain natural elements and conditions.

- Building/ Spatial Requirements: This considers the individual structures required for distinct functions and the necessary spaces they contain to serve different purposes. It also considers movement patterns and relation between spaces.

- Construction Materials and Methods/Technology: Involves a review of the type of materials used for construction of the facility.

- Aesthetics: Considers how well the physical structure presents itself as appealing based on the general cognizance of beauty.

- Functionality and Comfort: To what level does the project satisfy or fulfill the purpose for which it has been built, while providing the required comfort for users particularly in response to natural factors (eg. Lighting, ventilation, shelter, sanitary needs, and emergency)

- Safety and Security: Provisions for avoidance of crisis situations and emergencies.

- Sustainability: Level of consideration for social, environmental and economic concerns/impacts (eg. Energy efficiency, resource management, carbon emission reduction, flexibility of purpose, and material use).

- Regulations and Standards from Recognized Authorities 

Universities

\subsection{Case Study : The Northumbria University Sports Central, Newcastle}

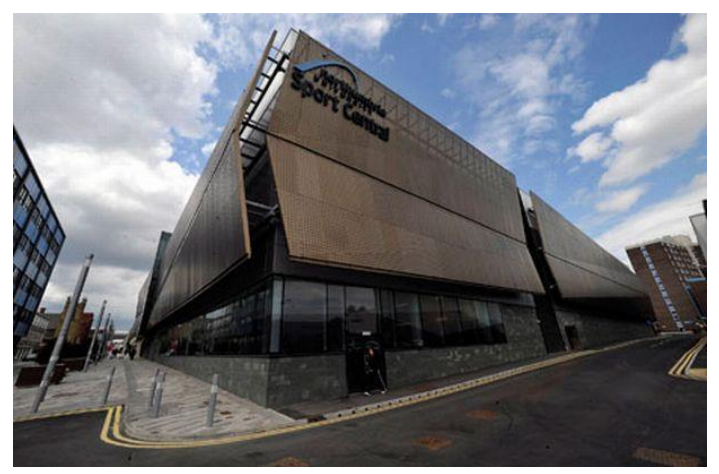

Fig1. The Northumbria University Sport Central, Atkins Project,Newcastle Source: Architects'Journal, 2017

Student Population: 35,000

Awards/Recognition:

- BREEAM Excellent Rating for Sustainability

- (Building Research Establishment Environmental Assessment Method)

- Top 12 most sustainable universities for sport in the United Kingdom (Telegraph, 2016)

Composition: The Sports Central Building, Atkins Project comprises of the following facilities;A 3,000 seating indoor arena, A 25 metre swimming pool, An indoor running/sprint track alongside sports research laboratories, Squash courts, Multi-use sports halls, A climbing wall

Composition: The Coach Lane Health and Fitness Centre comprises of the following facilities;Indoor courts, A multi activity sports hall, An exercise/ martial arts studio, A gym furnished with modern Techno gym fitness equipment, Multiple grass football pitches, A third generation rubber crumb football pitch (all-weather), An artificial turf pitch mainly for hockey and football (all-weather), Facilities for students to hire out and use with friends

\subsubsection{Major Considerations for Sustainability}

The Atkins project has achieved a BREEAM Excellent rating by featuring techniques like rain water harvesting to top up the swimming pool. Anodized aluminum cladding is used on external facades to provide 'visual interest' while semi-translucent cladding panels are featured at higher levels to allow natural light into the building.

Four white rectangular pods are built on the western façade, three contain meeting and teaching facilities and the fourth serves as the main entrance. On the southern façade, a thin vertical slot of structural glass allows passers-by to see the multi-storey climbing wall inside the building. Inside, the arena uses movable seats which means it can be tailored to specific events. When not in use the space can be converted into three separate sports halls.

\subsubsection{Merits}

Accessibility: Clear access to facility from major roads.

Building Character/ Visual Access: Character of physical structure is interesting.

Site Circulation and Movement: Clearly defined pedestrian circulation and movement paths. Parking spaces are positioned away from the facility.

Site Zoning: Clear zoning of activities to indoor areas, outdoor areas, swimming pool/aquatics.

Construction Materials and Technology: Construction is highly flexibility, with good use of lightweight materials. Outdoor court surfaces are finished with sustainable, all-weather materials.

Functionality and Comfort: Transition or movement routes from changing areas and showers to sports halls and outdoor courts are well considered.

Sustainability: The complex takes good consideration of sustainability. 
Reviewing Sustainable Sports Infrastructure: Implications for Sports Development in Nigerian Universities

\subsubsection{Demerits}

Layout: No particularly defined layout to the arrangement of facilities

Accessibility: Facilities are positioned in different campus locations making accessibility uneasy

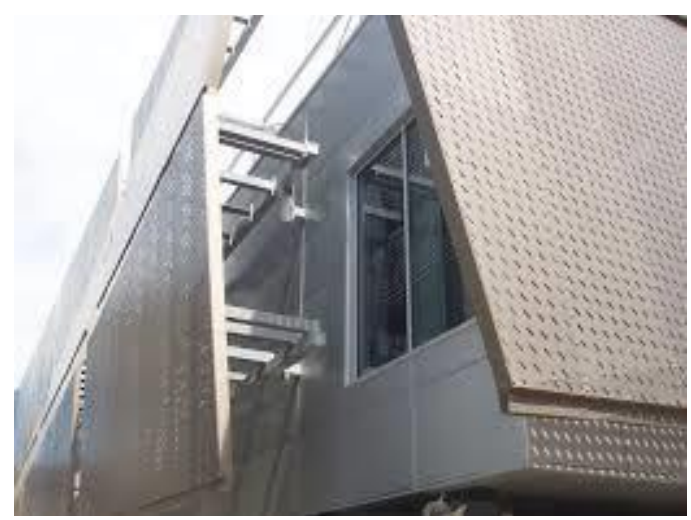

Fig2. Anodized Aluminum Cladding, A Sustainability Initiative

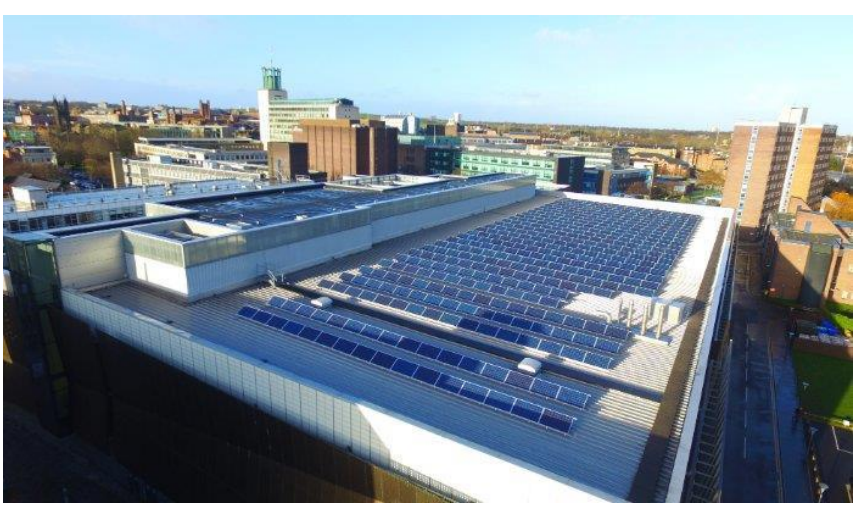

Fig3. Solar Panels and Rainwater Harvesting Systems

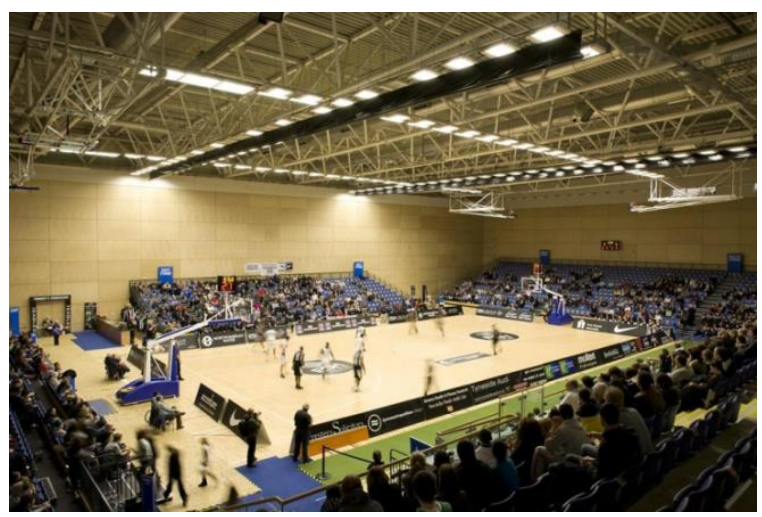

Fig4. Sports Hall with Adjustable Seating, A Sustainability Initiative

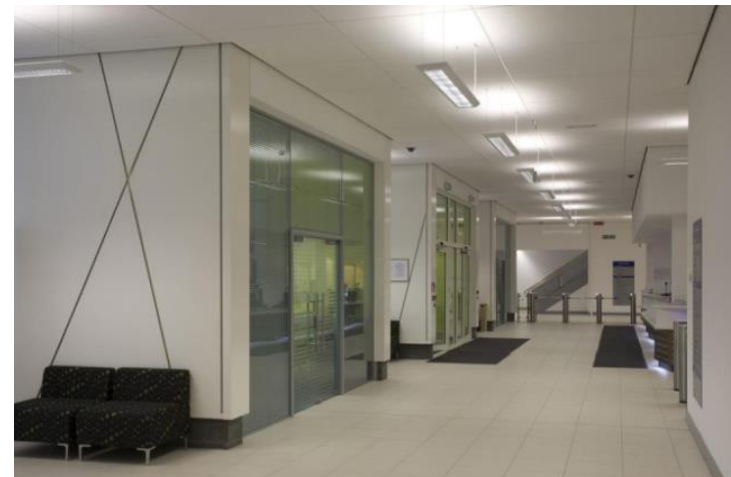

Fig5. Low Energy Lighting and Use of Lightweight Materials in Interior, A Sustainability Initiative 


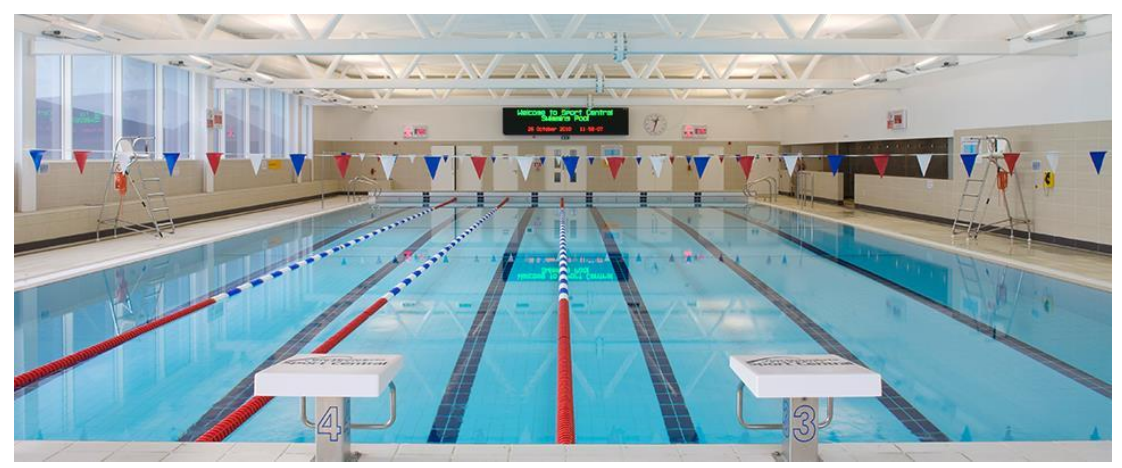

Fig6. Indoor Swimming Pool Powered by Recycled Rain Water, A Sustainability Initiative

\subsection{Case Study: The California State University Wildcat Center,Chico}

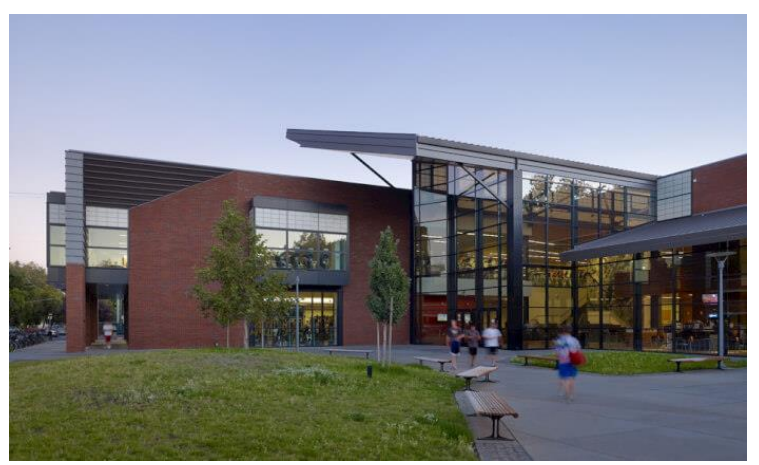

Fig7. Front View of the California State University Wildcat Recreation Center, Chico

Student Population: $\quad 17,557$

Awards/Recognition:

- USGBC LEED Gold (United States Green Building Council)

- Outstanding Sports Facilities Award, National Intramural-Recreational Sports Association

- Innovative Architecture \& Design Award, Recreation Management

- Honorable Mention for "High Res Impact," 3 Form Best Installation Contest

- Award of Merit: Higher Education/Research Category, ENR California Construction Best of 2010 Award, The McGraw-Hill Construction Magazine

- The Most Sustainable University Sports and Recreation Infrastructure Globally

- The Structural engineer of record received a national BIM award for this project for its detailed model effort using Revit \&Navisworks, for accuracy of the structural shop drawing creation and review

Composition: The California State University Wildcat Recreation Center comprises of the following facilities; 2 gymnasiums, 4 competition-size basketball courts, 6 handball/ racquetball courts, 2 swimming pools and an outdoor Spa, Tennis courts, Stadium and all-weather track, Soccer and multipurpose fields, Baseball stadium, Softball diamond, Putting greens and sand traps, Weight training/ Cardio room, Climbing wall, Dance studios, Athletic training rooms with running tracks.

\subsubsection{Major Considerations for Sustainability}

This LEED Gold certified project is located on a prominent southwest corner of the campus, the exterior materials and color palette draw from the campus's architectural history and the regional setting. The WREC is seen as a "family room" for the campus - an environment that is a safe, healthy, and affordable alternative to off-campus activities. Its popular sustainability features include: Waterless urinals, Elliptical exercise machines that generate power, A solar powered pool heater that's said to save up to $\$ 90,000$ per year in energy costs, Extensive use of natural lighting through translucent panels and views to the campus, Use of flexible, lightweight materials, Synergy of the 
Reviewing Sustainable Sports Infrastructure: Implications for Sports Development in Nigerian Universities

building structure with its indigenous environment, The lounge and refreshment bar which extends the gallery's social space for groups to meet or gather before or after workouts.

\subsubsection{Merits}

Site Circulation and Movement: Clearly defined and well-coordinated circulation or movement paths. Parking spaces are clearly defined and positioned away from building entrances.

Layout: The complex has a defined layout in core/courtyard arrangement.

Site Zoning/Arrangement: There is a clear zoning of activities to defined areas - stadium, indoor areas, outdoor areas, swimming pool and car park area. The facilities are all placed within proximity to each other.

Orientation/ Layout: The facilities are oriented according to recognized design standards and specification for outdoor courts and stadiums (ie. sun paths, wind directions, etc).

Sustainability: The complex is greatly inclined towards sustainability.

Building Character/ Visual Access: Character of physical structures is very interesting.

Construction Materials \& Technology: Construction is highly flexible. Primary material is steel and glass. Outdoor court surfaces are finished with sustainable materials.

\subsection{Study Location and Background Information}

The geographical location of the proposed project site is Nkpolu-Oroworukwo, which is situated fairly in the middle of Port Harcourt City, capital of Rivers State. The State is geographically located within latitudes 04045 " and 050 45" North and longitude 05015 " and 06050 ". It is bounded on the North, East and West by Imo, Akwalbom and Bayelsa States, and the South by the Atlantic Ocean respectively.

\subsection{Climatic Data and Analysis of Port Harcourt}

Climate has an important role to play as it affects the objective of the project, building orientation, choice of structural elements, as well as material suitability for construction in a particular area. As such a study of the prevailing climatic elements will provide the designer with necessary information and thus discover solutions towards achieving the design objectives optimally.

\subsubsection{Temperature}

Temperature values for Port Harcourt range between 210C and 340C. The highest values are recorded in the dry season from January to May and November to December. The wet season (July and August) present the lowest temperature values recorded. However, the stabilizing effect of the Atlantic Ocean, and a stratum of humid air over the area moderates this tropical condition. Comfortable conditions are established within the 100C - 240C range of temperatures. Excessive air movement and sweating is required to maintain comfort at above $280 \mathrm{C}$.

Temperature studies reveal that relatively high temperatures affect the texture and appearance of materials like paints and poorly seasoned timber. Also, plastics and bitumen experience distortion as it affects the texture and nature of these materials. It is therefore necessary to protect buildings from the effect of high temperature.

Design Considerations for the Effects of Temperature

- Selection and effective use roofing of materials which could minimize emission of solar radiation.

- Adequate ventilation should be provided for good air movement through interiors.

- Sunshades should be introduced to reduce heat resulting from incident sunlight.

- Proper orientation to reduce heating impact on buildings

- Adequate landscaping and provision of greenery to reduce heat reflection from surroundings into the building.

- Selection and use of effective insulating materials for construction of building fabric.

International Journal of Constructive Research in Civil Engineering (IJCRCE)

Page $\mid 28$ 

Universities

\subsubsection{Wind}

The South-West Monsoon and the North-East Trade winds are the prevailing winds in Nigeria. The velocities are relatively low, most often. However, during the rainy season the South-West monsoon which is more prevalent in the region brings about strong winds. Wind velocities on the average tend to be normal but sometimes it is considerably low and induces discomfort. The highest wind velocities are recorded in March, April, May and October. Strong winds could be destructive to building fabrics. Also, they often spread rainwater through the exterior and interior of buildings which results in damages. This is a critical concern for the designer

Design Considerations for Wind Effects

- Buildings should be positioned so as to take maximum advantage of prevailing wind conditions

- The use of wind breakers where necessary against the prevailing winds and its contents.

- Effective use of trees and other vegetation to buffer or break high wind impact

- Distance between buildings should be wide enough to allow for effective wind movement.

- Openings should be sufficient enough to allow for adequate air penetration.

\subsubsection{Sunlight}

Typically, there is more sunlight during the dry season compared to the rainy season when there are smaller amounts. This primarily, is due to the presence of cloud covers during the rainy season. The highest sunlight value of 4.8 hours is recorded in April while the lowest amount of sunshine which is 1.7 hours is recorded in August.Excessive heat in building interiors due to solar radiation from sunlight is a major challenge to architects and and it demands effective solutions.

Design Consideration for Effects of Sunlight

- The general building orientation as well as the organization of interior spaces should take good consideration of the cardinal points and sun movement paths according to purpose.

- Courtyards should be introduced where necessary to enhance the day lighting of interiors.

- Providing of adequate eaves and over hangs to reduce excessive sunlight.

- Effective use of horizontal and vertical shading devices like canopies, pergolas and fins to prevent direct sunlight from entering the building.

- Creative use of natural shading elements like trees, shrubs hedges

- Selection and effective use of materials which includes composition, resistivity/ reflectivity, colour, etc.

\subsubsection{Relative Humidity}

Relative humidity values for Port Harcourt fall within a $62 \%$ - $86 \%$ range. The month of July which is the peak of the rainy season records the highest value while January (dry season) records the lowest value of $62 \%$. The comfort zone associated with relative humidity is usually between $40 \%-60 \%$. Below $20 \%$, discomfort due to excessive dryness of air is likely and shrinkage and cracking of woodwork can also occur. At above $70 \%$ the air becomes damp and conditions uncomfortable. This will encourage fungi growth and dampness, causing damage to building fabric and materials.

Design Considerations for Relative Humidity Effects

- Provision for adequate ventilation of interior spaces to check formation of fungi and decay of organic matter.

- Proper orientation of the building to allow for balanced air movement through spaces as well as sufficient sunlight.

- Adequate fenestration for balanced air quality between indoor and outdoor spaces

International Journal of Constructive Research in Civil Engineering (IJCRCE) 

Universities

\subsubsection{Rainfall/Precipitation}

Rivers State records an average annual rainfall of about $300 \mathrm{~mm}$. The lowest monthly average is about $21 \mathrm{~mm}$ while the highest is $375 \mathrm{~mm}$. The highest rainfall value is obtained normally in July during the rainy season and the -lowest values in January and December in the dry season. Resultantly, provision of adequate drainages, concealing windows from wetness and protection of building walls are challenges which the designer must handle effectively.

Design Considerations for Rainfall/ Precipitation Effects

- Adequate extension of roof coverings (eaves), selection of suitable wall finishes or coverings and provision of adequate roof drains are a necessity in the combating rain effects on walls.

- Concrete roof slabs should be avoided and roof slopes should be steep enough to allow for quick and easy run-off of rain water.

- Strategies like recesses and shading devices like overhangs and balcony screens should be used effectively.

- Foot paths and walkways should be protected from rain impact.

- Ground floor slabs should be raised above identified water levels and membranes used effectively.

\subsection{Site Selection Criteria}

The specified land area for the proposed sports complex has been designated by the university in its' approved master plan. The site could possibly have been selected based on the following considerations:

- Availability of useable space: The site is an open piece of land, free of permanent infrastructure and can sufficiently accommodate the facility with extra consideration for future expansion.

- Topography: The site is relatively flat and this minimizes the challenges associated with complexity in design and construction.

- Soil Nature: The soil composition presents an adequacy for the project from an analysis of the existing projects surrounding the area.

- Drainage: No features of water logging on the site, even during the peak of rainy season.

- Accessibility: The site is easily accessible to both pedestrians and vehicles as it is situated close to roads regularly plowed by campus taxis. Also the university taxi park borders the site on one side.

- Nature of activities: The site is positioned at a distance away from lecture halls and hostels providing unrestricted expression for the activities it will host.

- Degree of privacy: The project could house activities which can attract people from outside the university community. As such, the site provides an acceptable level of privacy and security for the campus.

\section{INTERPRETATION/DESIGN DISCUSSION}

\subsection{Design Guidelines and Considerations}

Certain considerations are recognized as critical in the designing of sports facilities. Some of these are regarded as strict general guidelines based on recommendations from rigorous studies and research as found in the Neuferts Architects Data and Time Saver Standards. Some others present varying options open to the designer to identify the best suited to the immediate situation or scenario. However, new dimensions in architecture are defining that design practices consider present concerns which have the capacity to affect the future. These are the concerns of sustainability.

\subsection{Basic Components of the Proposed Sports Complex}

As its definition confers, a sports complex is a collection of facilities for a variety of sports, together in one place, and in some cases under one roof. The proposed sports complex draws on the Nigerian Universities Games Association recommendation which prescribes fifteen mandatory forms of sport as basic. These sports include: track and field, badminton, basketball, chess, cricket, handball, hockey, 

Universities

judo, football, squash, swimming, table tennis, taekwondo, tennis, and volleyball. As such, the facilities for these games will be provided within the complex. However, as certain games share certain similarities, they can be played on a single court.

The different types of sports are classified according to how and where they are played and this ultimately defines the kind of facility required. This classification includes:IndoorGames, Outdoor Games, Aquatics /Water Sports

The proposed sports complex will comprise of the following:

A Stadium with running tracks for track and field

Outdoor courts for the different outdoor games

An Indoor Sports Building for Indoor games

A Swimming pool for water sports

A. The Stadium (Amsterdam Curve type)

Games like Football, Athletics, Track and Field, Cricket, Field Hockey are played within the stadium in the presence of an audience. Components and necessary spaces within the stadium include:

Standard Football Pitch, 8-lane running tracks, Curves for Athletics, Jumps, Puts etc, 10,000 Spectator seating, Medic/ First Aid Rooms, Changing Rooms and Conveniences, Storage Rooms

B. Outdoor Courts for the Different Outdoor Games

Necessary Outdoor courts include:

Lawn tennis

Basketball

Volleyball

C. The Indoor Sports Building

A greater number of the games are played indoors and this influences the requirement for the indoor sports building. As such necessary facilities include:A multi-court sports hall for multiple games (to include basketball, volleyball, badminton, handball, table tennis and five-a-side football), Seating areas for spectators, Squash courts, A gymnasium, Combat sports halls (for taekwondo, Judo), Halls for table games (Chess), Changing rooms and Conveniences, Administrative Offices

D. A Swimming Pool for Water Sports

Main pool, Changing rooms and Conveniences

\subsection{The Design Philosophy}

This design project draws on multiple philosophies. First is the philosophy of Frank Lloyd Wright who presented the ideology that 'form and function are one'. This led to his creation of organic designs which flowed easily into surrounding terrains. As such, he recognized that there is an existent relationship between functionality and the local environment in designing for optimal results. This dimension has become a key content of the sustainability discourse in modern practice. The need for this project to identify with its indigenous environment is a priority, even as the various aspects of the project must identify and respond to prevailing factors.

In the second instance, Ludwig Mies van der Rohe, Stefan Sagemeister and Jonathan Ive all propose that subtraction is the key to a good design and not addition, birthing the phrase 'less is more'. The concerns of sustainability are considerably well-defined, precise and unambiguous - the reduction of carbon footprint on the environment due to human activities. This is primarily directed at achieving a greener atmosphere for improved human existence and continued well-being, which aligns with sports concerns. As such, the perceived simplicity inherent in this ideology can relate constructively to the carbon reduction concerns of sustainability through the elimination of complex processes affective to the design.

This project draws on these two philosophies in an attempt to achieve a facility which satisfies critical human concerns related to well-being, as well as fulfilling required objectives crucial to sustainability. 
Reviewing Sustainable Sports Infrastructure: Implications for Sports Development in Nigerian Universities

\subsection{Functional Requirements}

The project design is expected to cater to the sports infrastructural needs of the university. As such, several requirements which relate to specific functions will require the provision of specific spaces for specified tasks. These requirements will be provided based on already established analyses and set standards evident in the Neuferts' Achitects Data, the Time Savers Standards and The Architects Handbook, among others.

Several other facilities are recognized as necessary to the operation of the project. These include:

- Parking Lots for Cars and Buses

- A Pavilion for Meetings or Gatherings

- Food Courts

- Stalls/ Retail Shops

The concept of Sustainability and carbon emission reduction further places a need on the project to provide for certain facilities relevant to the dimensions it discusses. These facilities include:

- Water Recycling and Storage Systems

- Power Conversion and Storage Systems
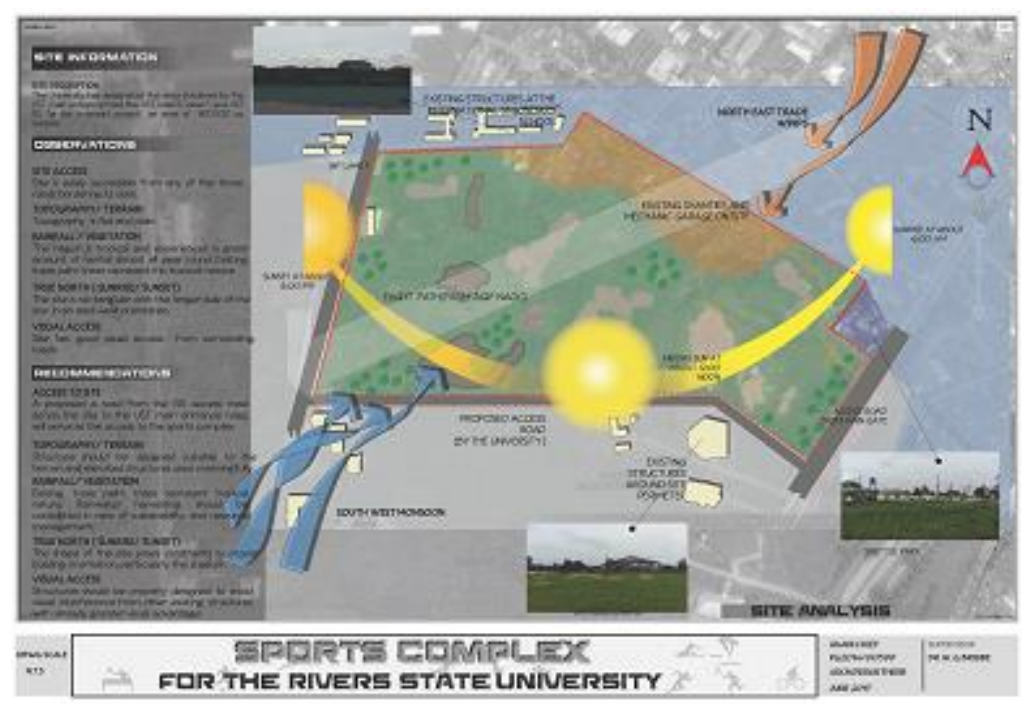

Figure5.1. Site Analysis

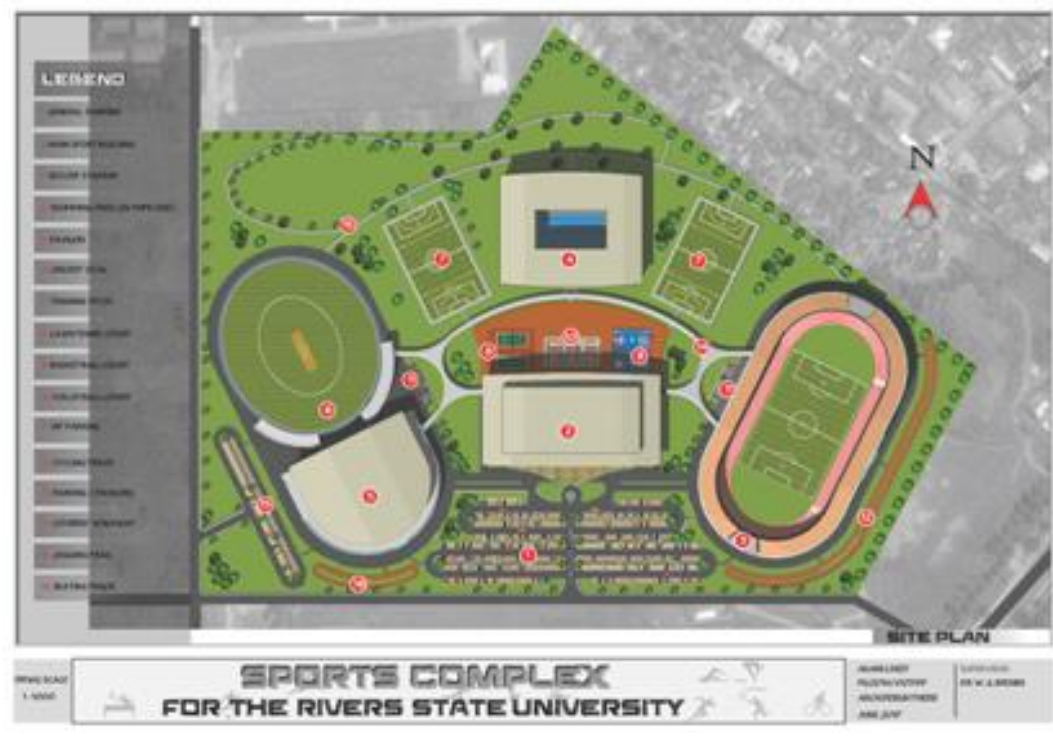

Figure5.2. Site Plan 
Reviewing Sustainable Sports Infrastructure: Implications for Sports Development in Nigerian Universities

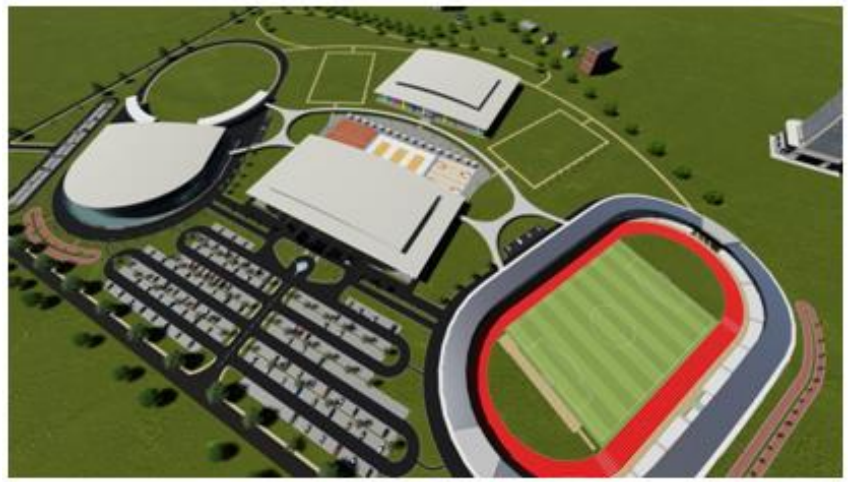

Figure5.3. Perspective View I

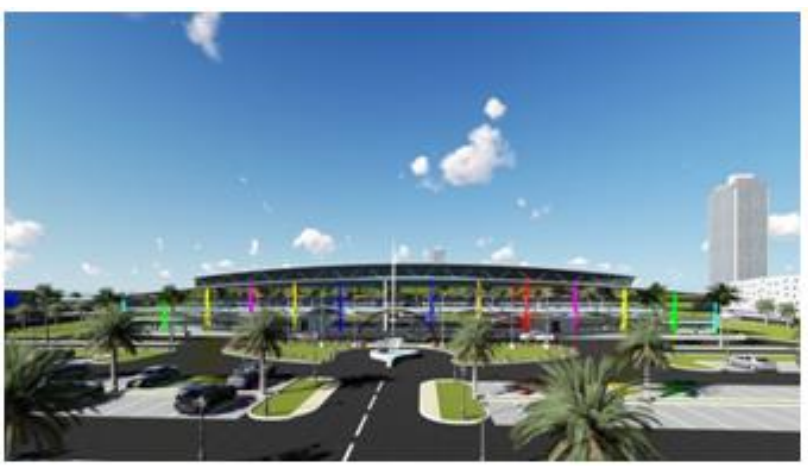

Figure5.4. Perspective View II

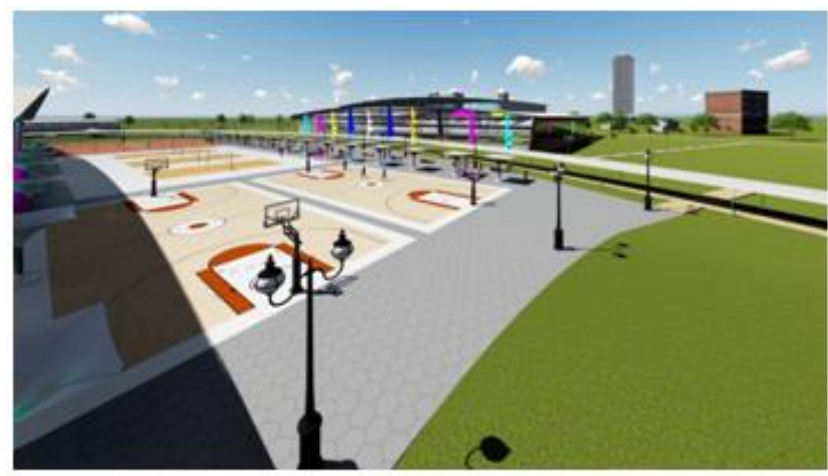

Figure5.5. Perspective View IV

\section{CONCLUSION AND RECOMMENDATIONS}

\subsection{Conclusion}

The relationship between Sports infrastructure, sustainability and student well-being has been reviewed through this research. The project culminated in a design responsive to recognized needs sports. Governments view sports as a platform for worker interactions across ministries and departments. Employers consider it a strategy for improved management - employee relations. Sports' interprets differently to various parties and offers a satisfaction to different kinds of need it is adapted to. As this research proves, it is necessary that adequate sports infrastructure is provided in response to needs, and to reduce negative impacts associated with its absence.

\subsection{Contribution to Knowledge}

This research work has identified critical dimensions from which sports participation can be improved, with the ultimate aim of improving student well-being in universities and tertiary institutions. As such, it improves the already existing bulk of knowledge on sustainability and sports infrastructural concerns. it has also primed new dimensions of thought for knowledge discovery and the further promotion of research as it suggests the opportunity for the provision of facilities for human kinetics and physical education studies and practice. 
Reviewing Sustainable Sports Infrastructure: Implications for Sports Development in Nigerian Universities

\subsection{Recommendations}

As the extents of sustainability are concerned with achieving positive long term benefits in a direct and indirect impact, the sustainable sports complex which this research work presents proposes a long term solution to sports infrastructural needs at the RSU.

- It is thus recommended that other considerations outside the scope of infrastructure which this study has undertaken but which are very critical to its achievement are rigorously considered.

- Sustainability in university sports infrastructure needs to be considered from a policy and regulations perspective, so that returns on such investments can be regrouped and the intended objectives satisfied.

\section{REFERENCES}

[1] Alahmed, M., Yusof, A.\& Shah,P. M. (2016) Mediating Role of Academic Attitude On Sports' Participation and Academic Performance.International Journal of Physical Education, Sports and Health, 3(4), 306-309

[2] Andrade de Melo, V. \&Bittencourt, M. (2012)The History of Sport for a Sports Country, Revista Tempo, 17(34), 1-10

[3] Annie, W., Howard, W. S. \& Mildred, M. (1996). Achievement and Ability Tests - Definition of the Domain, Educational Measurement, USA: University Press of America.

[4] Antón, A. J. \&Monroy, A. (2011). How Construction Trends of Universities Sport Facilities Will Be Affected by Financial Crisis: A Survey. Scientific Research and Essays. 6(9), 1998-2002.

[5] Aries, E., McCarthy, D., Salovey, P.\&Banaji, M. (2004). A Comparison of Athletes and Non-athletes at Highly Selective Colleges: Academic Performance and Personal Development. Research in Higher Education, 45, 577-602.

[6] Atkinson, J. L., Sallis, J. F., Saelens, B. E., Cain, K. L. \& Black, J. B. (2005). The Association of Neighborhood Design and Recreational Environments with Physical Activity.American Journal of Health Promotion, 19(4), 304-309.

[7] Azizi, B., Jalali-Farahani, M.\&Khabiri, M. (2012).Investigating the Attitude of Students'Living in Dormitories of Tehran Universities on Sport.Sport Management, 8, 91- 75.

[8] Bogar, C. T. (2012). Trends in Collegiate Recreational Sports Facilities.The Sport Journal.

[9] Broh, B. A. (2002). Linking Extracurricular Programming to Academic Achievement: Who Benefits and Why? Sociology of Education, 75 (1), 69-95.

[10] Byers, J. A. \& Walker, C. (1995). Refining The Motor Training Hypothesis For The Evolution of Play. The American Naturalist, 146, 25-40.

[11] Carroll, D. M. (2000). An Interdisciplinary Study of Sports As A Symbolic Hunt: A Theory of the Origin and Nature of Sport Based on Paleolithic Hunting. Lewiston, New York: The Edwin Mellen Press.

[12] Chad, K. E., Reeder, B. A., Harrison, E. L., Ashworth, N. L., Shephard, S. M. \& Schultz, S. A. (2005). Profile of Physical Activity Levels InCommunity Dwelling Older Adults. Medicine and Science in Sports and Exercise, 37 (10), 1774-1784.

[13] Chick, G., Loy, J. W. \&Miracle, A. W. (1997). Combative Sport and Warfare: A Reappraisal of the Spillover and Catharsis Hypotheses. Cross-Cultural Research, 31, 249-267.

[14] Covay, E.\&Carbonaro, W. (2010). After the Bell: Participation InExtracurricular Activities, Classroom Behavior, and Academic Achievement. Sociology of Education, 83(1), 20-45.

[15] Eccles, J. S., Barber, B. L., Stone, M. \&Hunt, J. (2003).Extracurricular Activities and Adolescent Development.Journal of Social Issues, 59, 865-889.

[16] Eibl-Eibesfeldt, I.(1989). Human Ethology. New York: Aldine de Gruyter.

[17] Fagen, R. (1981). Animal Play Behavior. London: Oxford University Press.

[18] Fejgin, N. (1994). Participation in High School Competitive Sports: ASubversion OfSchool Mission or Contribution to Academic Goals? Sociology of Sport Journal, 11, 211-230.

[19] Fox, C., Barr-Anderson, D., Neumark-Sztainer, D. \& Wall, M. (2010). Physical Activity and Sports Team Participation: Associations with Academic Outcomes in Middle School. Journal of School Health, 80(1), $1-55$.

[20] Gill, D. L. (2000). Psychological Dynamics OfSport and Exercise. Champaign, Illinois: Human Kinetics. 
Reviewing Sustainable Sports Infrastructure: Implications for Sports Development in Nigerian Universities

[21] Gill, D. L. (2000). Sport and Exercise Psychology Around the World. International Psychology Reporter, 4(3) 33-34

[22] Gratton, C. (2004). Sport, Health and Economic Benefit. In S. England (Ed.), Driving Up Participation: The Challenge For Sport Academic Review Papers Commissioned By Sport England As Contextual Analysis to Inform the Preparation Of the Framework for Sport in England. London: Sport England.

[23] Guttmann, A. (2004). Sports: The First Five Millennia. Amherst, Massachusetts: University of Massachusetts Press.

[24] Gyurcsik, N. C., Spink, K. S., Bray, S. R., Chad, K.\& Kwan, M. (2006). An Ecologically Based Examination OfBarriers to Physical Activity in Students From Grade Seven Through First-year University. Journal of Adolescent Health, 38(6), 704-711.

[25] Hadavi, F., Satchyan, V., Kalani, A., Rasoli, M.\& Ismail, M. (2014). Prioritizing Incentives For College Students to Participate in Sports Entertainment, Proceedings Of the First National Conference on Applied Research in Public Health and Sustainable Development.

[26] Hallmann, K., Wicker, P., Breuer, C.\&Schüttoff, U. (2011) Interdependency of Sport Supply and Sport Demand in German Metropolitan and Medium-sized Municipalities - Findings From Multi-level Analyses. German Sport University Cologne, Germany. European Journal for Sport and Society, 8(2), 6584

[27] Haug, E., Torsheim, T., Sallis, J. F.\&Samdal, O. (2008). The Characteristics Of the Outdoor School Environment Associated With Physical Activity. Health Education Research, 25(2), 248-256.

[28] Lahsaizade, A. (2007). Investigating the Factors Affecting Students' Interest in Sports: A Case Study of Shiraz University of Medical Sciences, Shiraz University, Journal of Humanities and Social Sciences, 24(2), 34-47.

[29] Limstrand, T. \&Reher, N. J. (2008). Young People's Use of Sports Facilities: A Norwegian Study on Physical Activity. Scandinavian Journal of Public Health, 36 (5), 452-459.

[30] Loy, J. W. \&Hesketh, G. L. (1995). Competitive Play on the Plains: An Analysis of Games and Warfare among Native American Warrior Societies, 1800-1850. In Pellegrini A. D. (Ed.), The future of Play Theory: A Multidisciplinary Inquiry into the Contributions of Brian Sutton-Smith. Albany, New York: SUNY Press.

[31] Mahoney, J. L., Cairns, B. D.\& Farmer, T. W. (2003). Promoting Interpersonal Competence and Educational Success Through Extracurricular Activity Participation. Journal of Educational Psychology, 95, 409-418.

[32] McArdle, J. J., Paskus, T. S. \&Boker, S. M. (2013). A Multilevel Multivariate Analysis of Academic Performances In College Based On NCAA Student Athletes. Multivariate Behavioural Research, 48 (1), $57-95$.

[33] Melendez, M. (2006). The Influence of Athletic Participation On the College Adjustment of Freshmen and Sophomore Student Athletes. College Student Retention, 8(1), 39-55.

[34] Lombardo, M. P. (2012)On the Evolution of Sport, Grand Valley State University, Journal of Evolution and Psychology, 10(1) 8-13.

[35] Mirzazadeh, Z. S., Ahmadi, Y. \&AlahmadiA. J. (2015)Identifying Affecting Factors for the Increase in Student Participation in Physical Activity and Solution. European Online Journal of Natural and Social Sciences.4(1)1-10.

[36] Muñoz-Bullón, F., Sanchez-Bueno, M. J. \&Vos-Saz,A. (2016).The Influence of Sports Participation on Academic Outcomes among Students in Higher Education: A Case Study. Madrid: Universidad Carlos III de Madrid

[37] Poliakoff, M. B. (1987). Combat Sports in the Ancient World: Competition, Violence, and Culture. New Haven, Connecticut: Yale University Press.

[38] Position Statement of the European Federation of Sport Psychology (FEPSAC) (1996): The Definition of Sport Psychology. The Sport Psychologist, 10, 221-223.

[39] Prasad, V. V. (2012) Students and Sports: The Association between Participation in Sports and Academic Achievement. Albany, New Zealand: Massey University

[40] Robert, L. (2012). Impact of Campus Recreational Sports Facilities and Programs on Recruitment and Retention Among African American Students: A Pilot Study. Recreational Sports Journal, 33(1)25-34.

[41] Sansone, D. (1988). Greek Athletics and the Genesis of Sports. Berkeley, California: University of California Press. 
Reviewing Sustainable Sports Infrastructure: Implications for Sports Development in Nigerian Universities

[42] Sasaki Group(2017) The California State University Images. Retrieved from http://www.sasaki.com/project/57/california-state-university-chico-wildcat-recreation-center17/05/2017.

[43] Silliker, S.\& Quirk, J. (1997). The Effect of Extra-curricular Activity Participation On the Academic Performance of Male and Female High Students. The School Counselor, 44, 288-293.

[44] Simons, H. D., Van Rheenen, D.\& Covington, M. V. (1999).Academic Motivation and the Student Athlete.Journal of College Student Development 40, 151-162.

[45] The Architects'Journal (2017) Northumbria University Sports Central. Retrieved from http://www.architectsjournal.co.uk/home/atkins-completes-northumbria-university-sport-centralbuilding/8612227.article28/05/2017.

Citation: BRISIBE, Warebi G, AKANI, Chizy, "Reviewing Sustainable Sports Infrastructure: Implications for Sports Development in Nigerian Universities", International Journal of Constructive Research in Civil Engineering, 6(1), pp. 19-36. DOI: http://dx. doi.org/10.20431/2454-8693.0601003.

Copyright: (C) 2020 Authors, This is an open-access article distributed under the terms of the Creative Commons Attribution License, which permits unrestricted use, distribution, and reproduction in any medium, provided the original author and source are credited. 